\title{
SIM PAUD Application Training in Improving Teacher IT Skills at PPT Permata Hati Bendul Merisi Wonocolo District
}

\author{
Firda Rizqy Amalia1, Suryanto² \\ ${ }_{1,2}$ Human Resource Development, Universitas Airlangga, Indonesia
}

\begin{abstract}
As science and technology advance along with the growth of industry 4.0, teachers are expected to adjust their skills to current demands. In a specific subject, skills or knowledge defined by professionalism become an essential item as the field's flagship. Competence is required in all disciplines, including teaching methods. The role of teachers in educating and attempts to maximize all brain cells in children are inextricably linked to the success of Early Childhood Education. Given the golden age in humans is 0-6 years. Thus, this study aims to identify the readiness of teacher competencies to educate students in the face of an ever-increasing flow of technology. The objective of this study was to discuss the IT training provided at PPT Permata Hati to help teachers enhance their IT skills in creating online lesson plans. A qualitative method was employed in this study, utilizing a case study approach. Data was gathered through interviews, documentation, and activity pictures. The results of this study revealed the progression of the educational process at PPT Permata Hati in Bendul Merisi Village, Wonocolo District, from the creation of learning activity plans by teachers using the SIM PAUD application to online performance reporting through the Surabaya City Department of Education's website. The training outlined the principal's training, which included everything from an introduction to using the program. A presentation and on-the-job training methodology were employed as the training model. The originality or value of this study is that it discusses the training given to early childhood teachers on how to use the Surabaya City Department of Education's information technology "PAUD SIM" to create Weekly Learning Implementation Plans. The implication of this research was done to prepare for the needs for training, both in the form of infrastructure and logistics needed. The existence of SIM PAUD as a means of exchanging information on the performance of educators, absenteeism, weekly Learning Program Plan documents between schools, teachers, and the Surabaya city education office.
\end{abstract}

Keywords: training, educators, human resources, science, and technology.

\section{INTRODUCTION}

This is an open access article under the CC-BY-NC license.

Environmental conditions and rapid technological advances influence increasingly advanced education. This progress can be seen from technology development that allows for easier and faster access to information. Rapidly growing information cannot be separated from the developments in computer engineering. The most influential application in computer technology and information technology in the field of education is the use of computer networks and the internet. (Mikrotik, 2014).

Technological progres will not be able to run optimally if the available resources cannot keep up. In this case, the resources in question are human resources and artificial resources such as technology, the internet, infrastructure, and others. The main human resources in the education sector are educators. The ability of educators to face the era of increasingly advanced technology.

Education in the development process provides a very large contribution to the progress of a nation because education is a means of building the character of the nation. Program policies to improve the quality of education cover three main aspects: first, the development of a sustainable curriculum at all levels and types of education. Second, improve the welfare and professionalism of teachers. Third, the utilization of educational facilities and infrastructure (Mulyasa, 2014).

In terms of manpower, the low quality of human resources is a fundamental problem that can hinder the development of the national economy. In discussions at school, teacher competence is extremely important to student activities and learning outcomes (Mustari, 2014). Therefore, we 
need qualified teachers who have the will and ability to continuously improve their quality (continuous quality improvement) (Mulyasa, 2014).

The current conditions that have occurred since the emergence of the COVID-19 viruses in 2019, which have not yet reached their peak in 2021, require that the online learning process be good (Kamil, 2021). The process in this network is to minimize physical contact between humans, maintain a safe distance, and stop the spread of the existing virus. So the learning planning process, learning activities, to reporting learning outcomes must use the internet. This is regulated in circular letter No. 15 of 2020 on Guidelines for Organizing Learning from Home in an Emergency Period for the Spread of Coronavirus Disease (COVID-19). This rule is based on the first law of Government Regulation No. 17 of 2010 on Management and Implementation of Education as amended by Government Regulation No. 66 of 2010 on Amendments to Government Regulation No. 17 of 2010 on Management and Implementation of Education. And second, Regulation of the Minister of Education and Culture No. 33 of 2019 on Disaster Safe Education Units (Kebudayaan, n.d.).

Based on the background described previously, the following research questions were formulated: 1. How is the training implemented by the school for educators in dealing with era 4.0 education at PPT Permata Hati?

2. How is the training process for teaching performance results reported online (in the network)?

3. What training model does the principal apply to teachers at PPT Permata Hati?

based on research questions, the objectives of this study are:

1. describe the training implemented by schools to educators in dealing with education in the 4.0 era

2. describe the training process of teaching performance results reported online (in the network).

3. describe what training model is applied by the principal to teachers at PPT Permata Hati

\section{LITERATURE REVIEW}

According to Soekidjo Notoatmadjo, human resource management or personnel management acknowledges the importance of human resources or labor in organizations and their use in various functions and activities to achieve organizational goals (Keselamatan et al., 2014).

The operation of total quality management in education has several main things that need to be considered, namely, continuous improvement, where this concept implies that the manager always makes various improvements and continuous improvements to ensure that all components of education providers have achieved the quality standards applied. It also means that the institution is always trying to update the process as needed (Sallis, 2012).

The existence of a continuous improvement process requires good human resource management. Various terms regarding human resource management are used, namely human resource management (HRM), personnel management, labor management, personnel administration (employment), and industrial relations. Human resource management emerged as a new problem in the 1960s; before that, more or less in the 1940s, personnel management was dominant (Sukrispiyanto, 2019).

Human resource management is part of general management that focuses on the people owned. The HR management functions and general management functions are managerial: planning, organizing, directing, controlling. Operational Functions: manpower procurement, compensation, integration, maintenance, termination of employment. In educational institutions, education personnel in general are: (1). Educational staff consists of educators (teachers, supervisors, examiners), education unit managers, librarians, laboratory assistants, and other learning resource technicians. (2). Other personnel who deal with managerial or educational administrative matters (Suparto, 2016). 
Training is a process by which a group of people can achieve certain abilities to help achieve organizational goals. Therefore, this process is tied to various organizational goals; training can be viewed narrowly or broadly. On a limited basis, training provides employees with specific and recognizable knowledge and skills used in their current job. Sometimes there is a line between training and development, with development being broader in scope and focusing on the individual to achieve new abilities that are useful both for his current job and future, According to Mathis (Hakim \& Si, 2007).

Gary Dessler (2009) defines training as the process of teaching new or existing employees the basic skills they need to carry out their jobs. Training is one of the efforts to improve the quality of human resources in the world of work. Employees, both new and old, need to attend training because of job demands that can change due to changes in the work environment, strategies, and so on.

The general purpose of the training provided to the target is to develop expertise in a particular field to complete work according to predetermined targets. In addition, the purpose of training is to add insight to develop knowledge so that work can be completed rationally. And the last is to develop an attitude of good cooperation among employees, colleagues, and managers (Sedarmayanti, 2009).

Methods in training have various types according to the objectives to be achieved. According to John, there are 12 training methods (Nugroho, 2019):

1. Presentation method

This method focuses on the quality of communication with a passive one-way or two-way communication system. Participants receive material directly from the instructor with the concept of studying in general. The information conveyed can be in the form of data, facts, and problem-solving techniques.

2. Lecture method

The method takes place when an instructor communicates verbally to the participants. This method can be said to be effective if an instructor is the only good source of information. In addition, the instructor can provide a lot of information. However, the weakness of this model is that it will create a boring atmosphere due to the one-way communication.

3. Method of discussion or conference

This method goes both ways, giving each other feedback on the theme being discussed. Various kinds of media can be used to support the information or the smooth delivery of messages. The advantage of this method is that feedback is not only the focus of the instructor.

4. Audiovisual method

This method is supported by the use of audio and visual devices such as slide shows, overhead, video, and so on. This tool aims to support a more effective information delivery process. The use of video in training will improve the reasoning ability of the participants and even the technical ability of how a training content is presented attractively and visualized in a structured manner.

5. On-the-job training method

In this method, participants will be actively involved in every activity organized by the instructor. This method takes place when a team member experiences the learning process in work activities directly. Managers or mentors will provide examples of how to carry out various sets of work processes.

6. Self-directed learning method

The trainees are personally responsible for the training materials and the learning process. They study the content or material they get. The role of an instructor is as a facilitator who wants to be asked.

7. Apprenticeship Method

This method can also be referred to as the apprenticeship method, an activity that can be done outside the classroom. This means that participants can directly practice in the internship place. This method is effective if the goal is to gain knowledge, skills, and work skills through work experience.

8. Simulation Method 
Training on the actual situation brought into the scope of the training as if in that situation a simulation can also be carried out using games or games.

9. Case study method

A description of the real situation that is brought into the training and used as training material. The difference with simulation is that the case has already occurred and is discussed to find the best solution.

10. Business games method

In this method, participants are required to identify all the information provided, analyze and then make decisions regarding the problems in the game.

11. Roleplay method

This method is also referred to as the role-playing method on several occasions. Participants who acted as a trainer wrote that this method was the most fun. In the context of work, roleplaying can be modified in such a way that it can be applied to the situation and conditions of the company.

12. Behavior modeling method.

This method is based on the principles of social learning theory. Participants were asked to look at an example of a person demonstrating behavior that they should imitate and practice. There are two important things about this method: learning does not occur because of the observation of certain behaviors shown by a model. Secondly, reinforcement occurs in a person through behavior change.

Information technology is limited to computer technology (hardware and software) that will be used to process and store information and includes communication technology to send/disseminate information (M Husaini, 2014). Computer technology is technology related to computers, including computer-related equipment. Medium communication technology is technology related to long-distance communication devices, such as telephone, fax, and television. When used wisely for education and training, technology can improve quality and reach and has a very important meaning for well-being (Haris Budiman, 2017).

\section{METHODOLOGY}

This research was a case study where the researcher observed what was being studied in descriptive form. A case study is a type of qualitative approach that examines a particular "case" in the context of contemporary real-life (Sugiyono, 2018). This research was conducted at the Permata Hati Integrated Early Childhood Education for non-formal early childhood education. Students who study at this school have a range of ages from 2 years to 5 years. It is located on Jl Bendul Merisi Indah no 3 Surabaya, Bendul Merisi village, Wonocolo District, Surabaya City.

The subjects in this study were selected purposively who were judged to have the capacity as informants, namely PPT Permata Hati educators as the party conducting the treatment, school operators as web holders, and parties controlling virtual activities carried out, vice principal in the curriculum field as the person in charge, the running of the education process, and the principal as the manager and decision-maker on the policies set at the school.

Data collection in this study used: (1) interviews with related parties, (2) blog or website observations (3) data collection, document analysis. This study used an analytical induction approach, which was based on the problem or research question. Mason stated that the data collection technique was developed through analysis of the data sources of each research question, then the data collection techniques were; (1) qualitative interview, (2) participatory observation, (3) document analysis, and (4) site analysis with interview preparation and planning procedures (Sugiyono, 2018). Researchers took pictures of what they wanted to study, also described their position as instruments in the data collection process. Therefore, the validity of the data in this study is effective and can later produce a result that can be accounted for validity and accuracy.

This study used an interactive model of data analysis. Miles and Huberman (Sugiyono, 2018) stated that empirical data and then looking for abstractions could be analyzed by interactive model analysis. The data analysis used in this research was interactive model analysis, namely data collection, data display (data presentation), data reduction, conclusion: drawing or verification, and data within the realm (infield) and outside the realm. Validity and reliability of data in this research ensured using qualitative model, i.e., reference correspondence and member check. 
The existence of a continuous improvement process requires good human resource management. Various terms regarding human resource management are used, namely human resource management (HRM), human resource management, personnel management, labor management, personnel administration (employment), and industrial relations. Human resource management emerged as a new problem in the 1960s; before that, more or less in the 1940s, personnel management was dominant.

\section{RESULT AND DISCUSSION}

The existence of information technology for the world of education means the availability of channels or facilities that can be used to spread learning programs both unidirectionally and interactively. The utilization of information technology is essential considering the geographical conditions of Indonesia, in general, are in mountainous areas which are scattered into many islands. With the advent of information technology, it is now possible to hold remote learning, allowing for the equal distribution of education throughout Indonesia's territory, including those that can be accessed by land transportation and those that cannot.

The existence of technological advances must be balanced with the ability of human resources owned. In this context, the teacher becomes the main human resource. Capacity development at PPT Permata Hari is carried out through training. It is intended that the human resources owned can be competitive with educators from other schools and increase the capacity to carry out the learning process for students. The training provided by school principals from sub-district offices is carried out representatively by gathering school operators in one place to later be able to transmit this knowledge to other teachers in the scope of work of school operators.

The principal prepares activities by determining the needs during the training, namely the availability of infrastructure suggestions such as laptops, internet connection networks, lighting, comfortable places, to the necessary logistics. After the plan is formed, the training is carried out. The training was carried out through the principal explaining in advance the components of how to enter the server, then selecting the sub-chapters that were accessed. The following is a management information system application used in PPT Permata Hati.

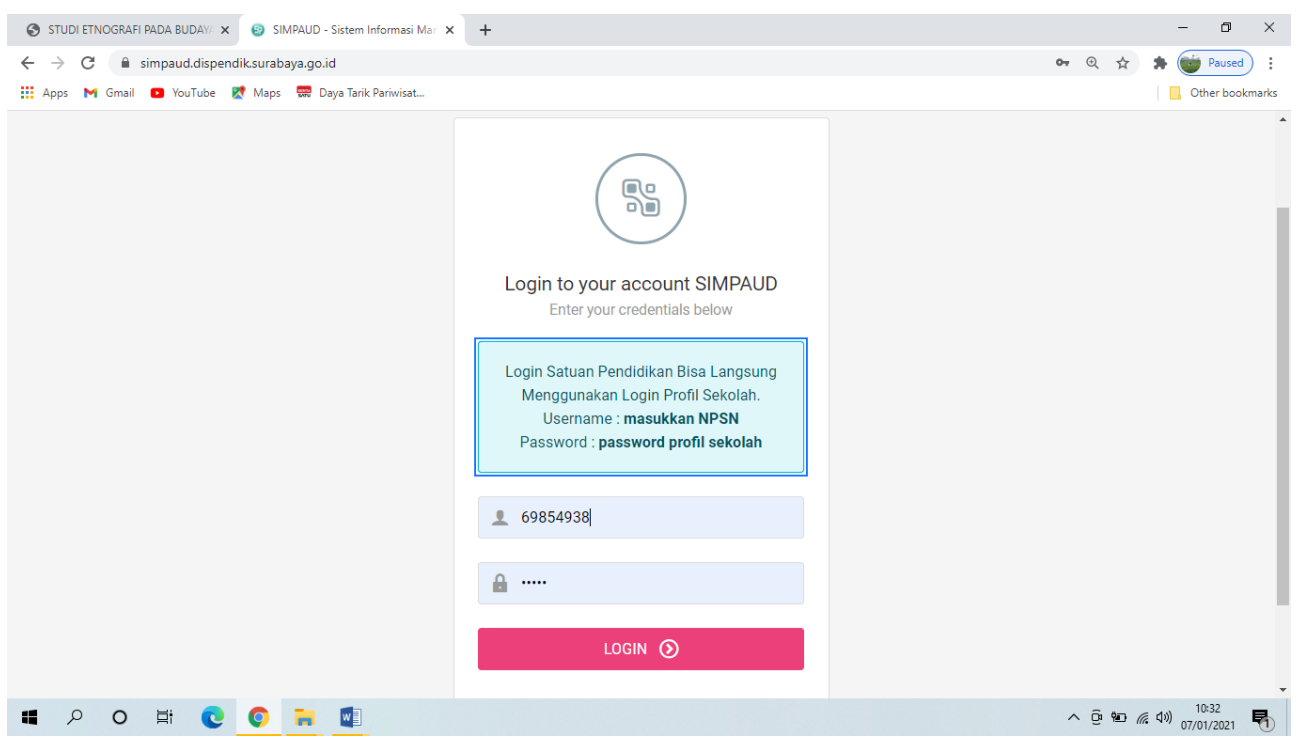

(1) Initial image will access PAUD SIM server

This application contains various features that can be used to exchange information between school principals, educators, city education supervisors, or supervisors. This study focuses on training in making learning program plans. Teachers and principals can enter as an education unit. Meanwhile, the supervisor acts as an observer and data monitor. Teachers and principals can access the education unit web by entering the NPSN. 


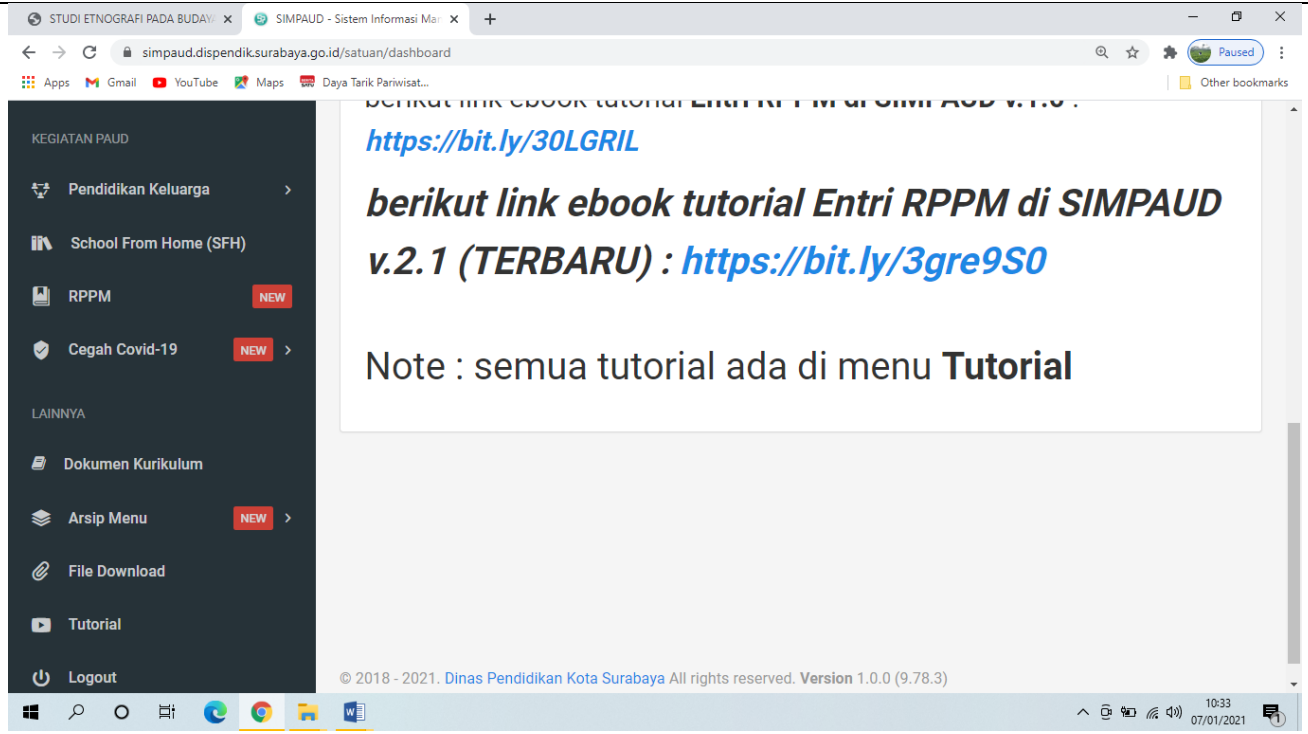

(2) List of menus and guidance links provided by the education department of Surabaya city.

The education office provides independent tutorial facilities for teachers who want to learn individually. Teachers can pay attention to video tutorials made by the education office. The video can be played and stopped according to the needs and understanding of the teacher, but the teacher cannot ask what questions if some errors and problems are not understood. The ability and understanding of information technology are needed to match today's needs (M Husaini, 2014).

Independent videos of the use of the weekly learning program plan application include examples on the selection of learning themes, the required period, the teaching semester, the month of activity, the time from the start of learning to the target date of completion of learning.

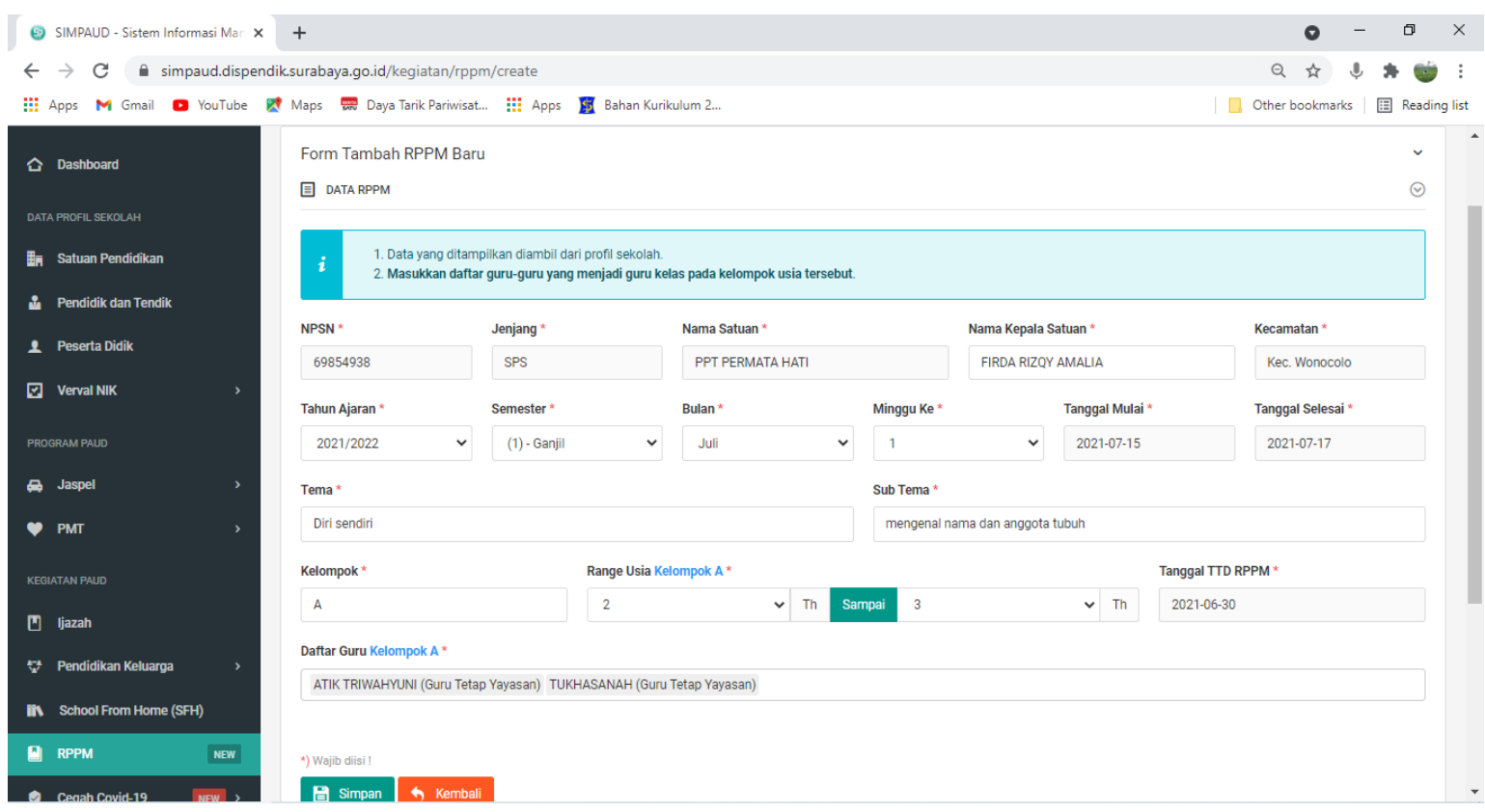

(4) This is the appearance of the new RPPM form

In this form, some data need to be done according to the needs. Starting from the selection of learning themes, the semester in learning activities, the month of learning implementation, the start of the time to the end date. Don't forget the name of the teacher who made the RPPM. 


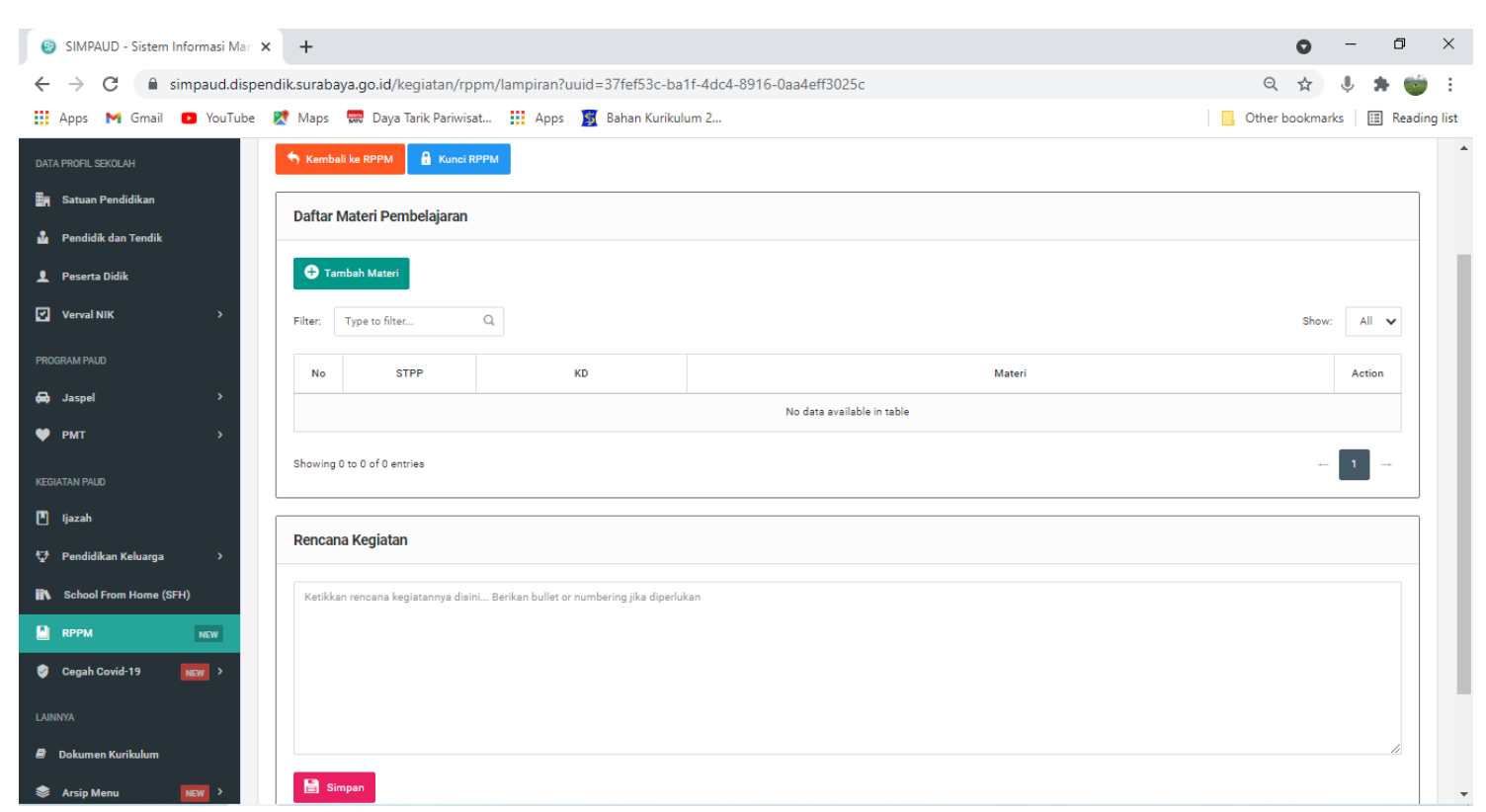

(5) Image of the display of compiling the RPPM for early childhood education

In this column, the teacher can enter the indicator competencies and basic competencies to be achieved during the learning process in this RPPM. Then the teacher can write down the materials to be carried out. For example, the teacher wants to achieve basic motor competence, the teacher will provide activities in the form of cutting and sticking to improve fine motor skills and provide ball-throwing activities to improve gross motor skills in students.

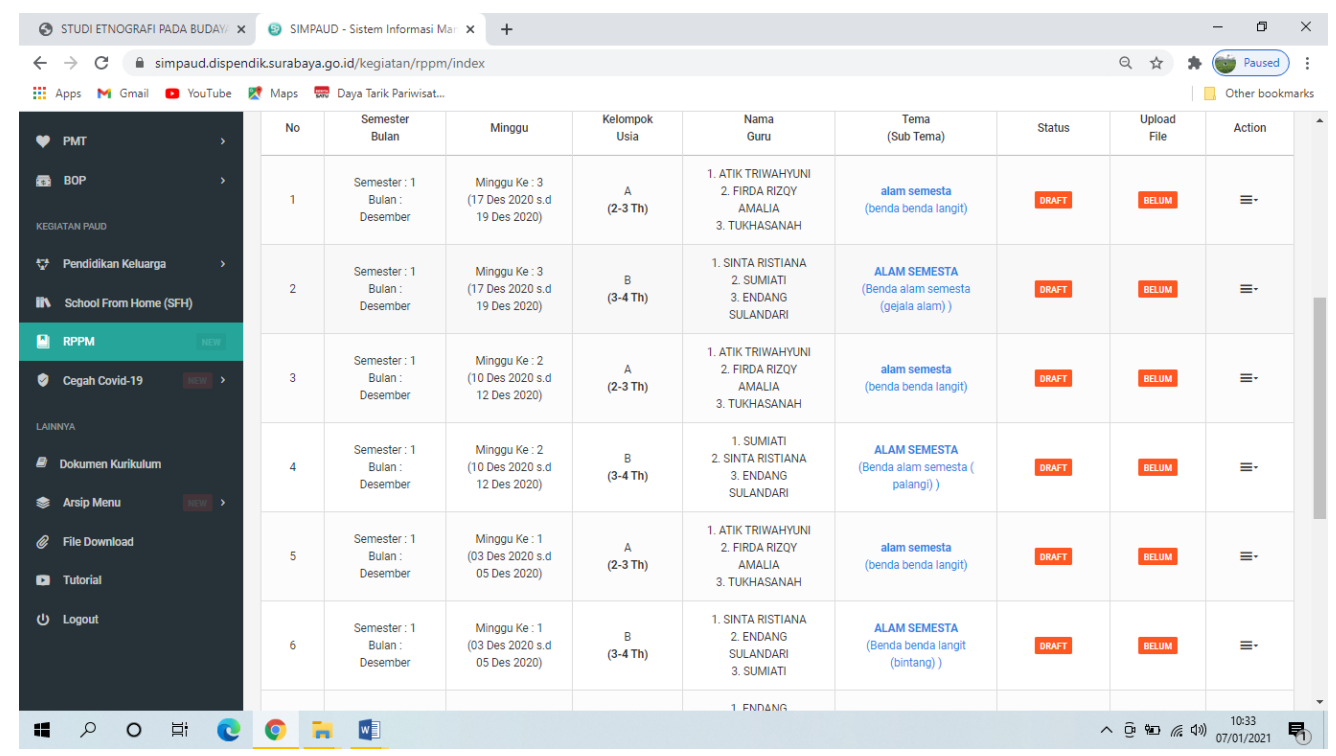

(7) Display of lesson plans that educators have previously made at PPT Permata Hati.

What if the teacher has felt enough in writing the lesson plan? Then the principal will explain the next procedure, namely by saving the draft then printing and uploading it so that the supervisor can assess the lesson plan that has been made. Supervisors can provide input and direction to grant implementation permits to educational units. 


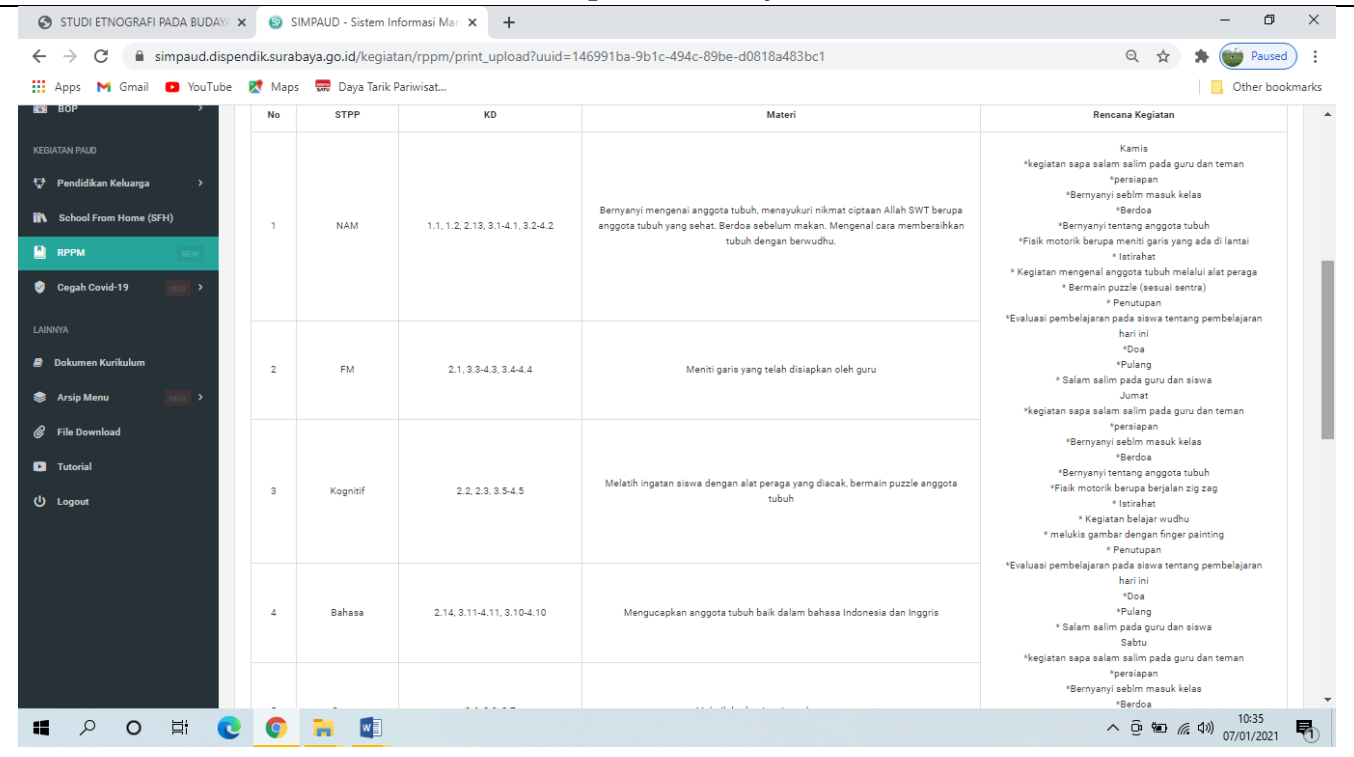

(8) The results of one of the RPMs were made based on the training provided by the principal with the school operator to all educators in PPT Permata Hati.

The training is carried out using the on-the-job training model because it is based on all educators in every activity organized by the instructor. This activity took place at the beginning of the principal, providing directions and examples in the implementation of the information system operation. The training is carried out for 3 days with a period of 3-4 hours per day to maximize knowledge and avoid mistakes in the future.

The educators are divided into 2 large groups based on the teaching class: class A which educates students aged 2-3 years, and group B, which educates students aged 4-5 years. Educators prepare plans for learning activities directly on the application and will later be corrected by the principal. The results of the evaluation will be submitted at the end of the training activity meeting. In addition to direct training with instructors, teachers, or educators at PPT, Permata Hati can use the video tutorial facility in using the PAUD SIM application to increase their knowledge.

The obstacles found were the discipline of educators and the shame of educators in asking when they did not understand. Finally, an error occurred in entering data. But this is communicated and find a solution together.

In addition to preparing a program of teaching activities, this application can include teacher performance results in the form of online teacher attendance, which can be reported directly to the Surabaya City Education Office. Attendance is carried out individually by providing what information must be done and what data is needed in reporting teaching activities to the Education office. 
International Journal of Emerging Issues in Early Childhood Education (IJEIECE) Vol. 3 (2), 18-27 SIM PAUD Application Training in Improving Teacher IT Skills at PPT Permata Hati Bendul Merisi

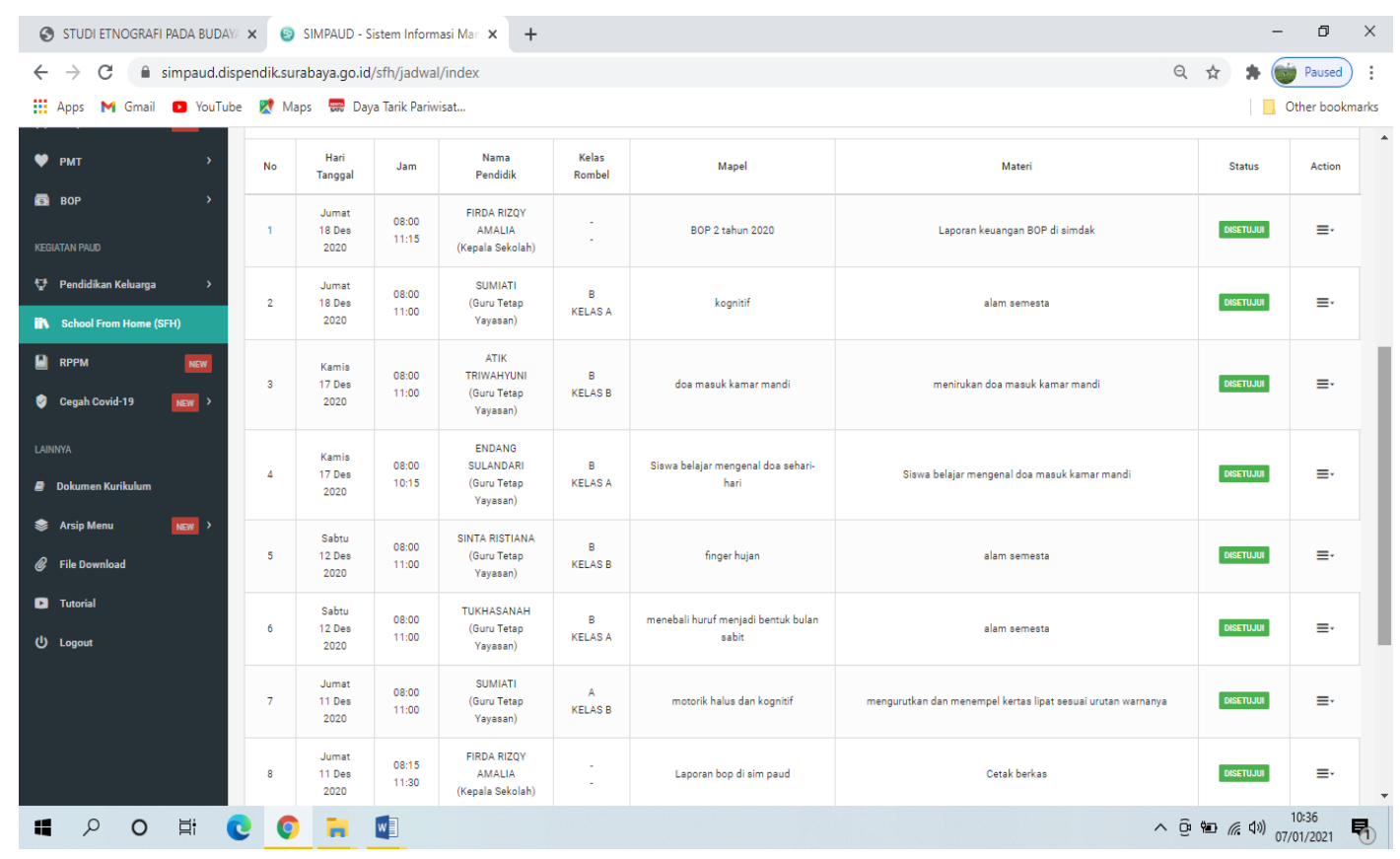

(9) Display attendance for teaching and learning activities and reports on the performance of school principals to supervisors, which the Surabaya City Education office operator can also access.

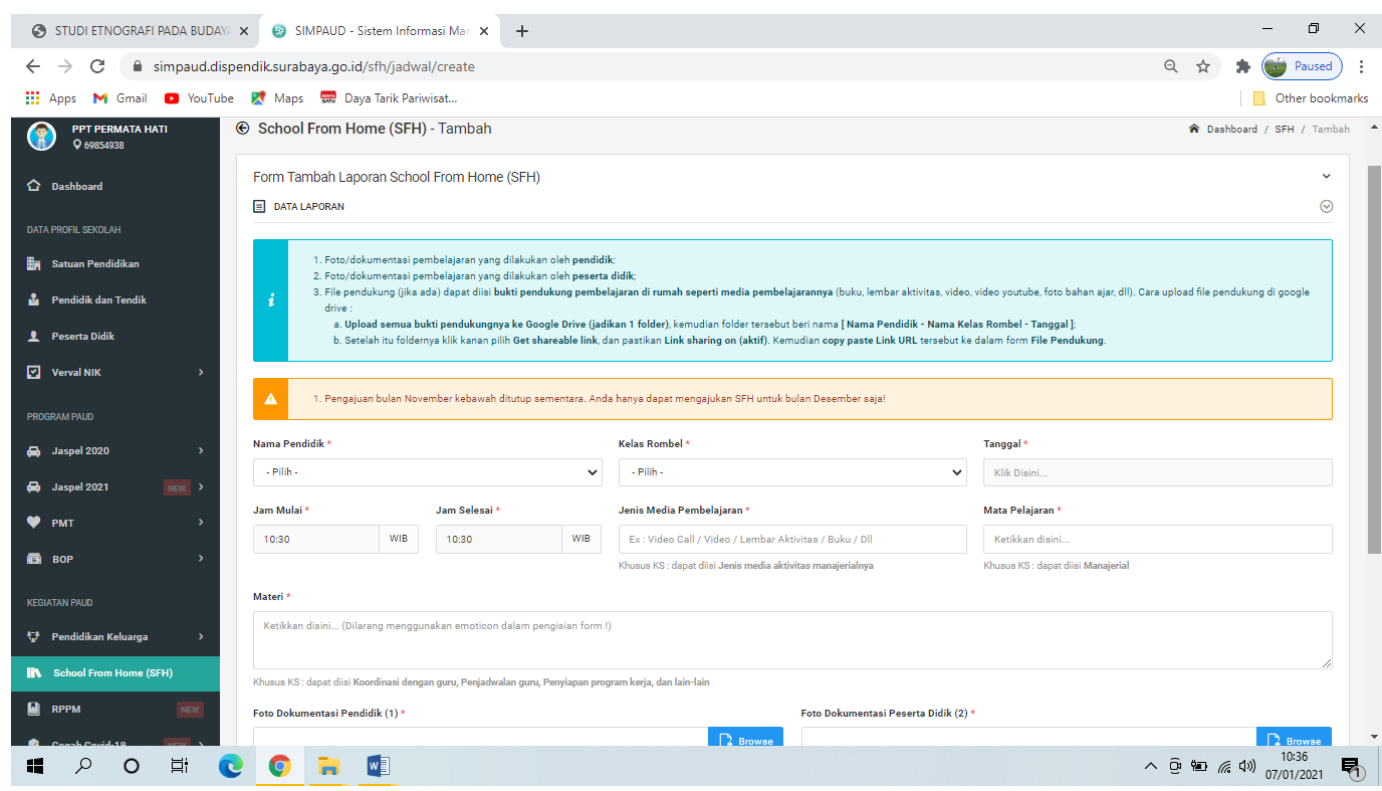

(10) The form of absenteeism performance that must be reported. 


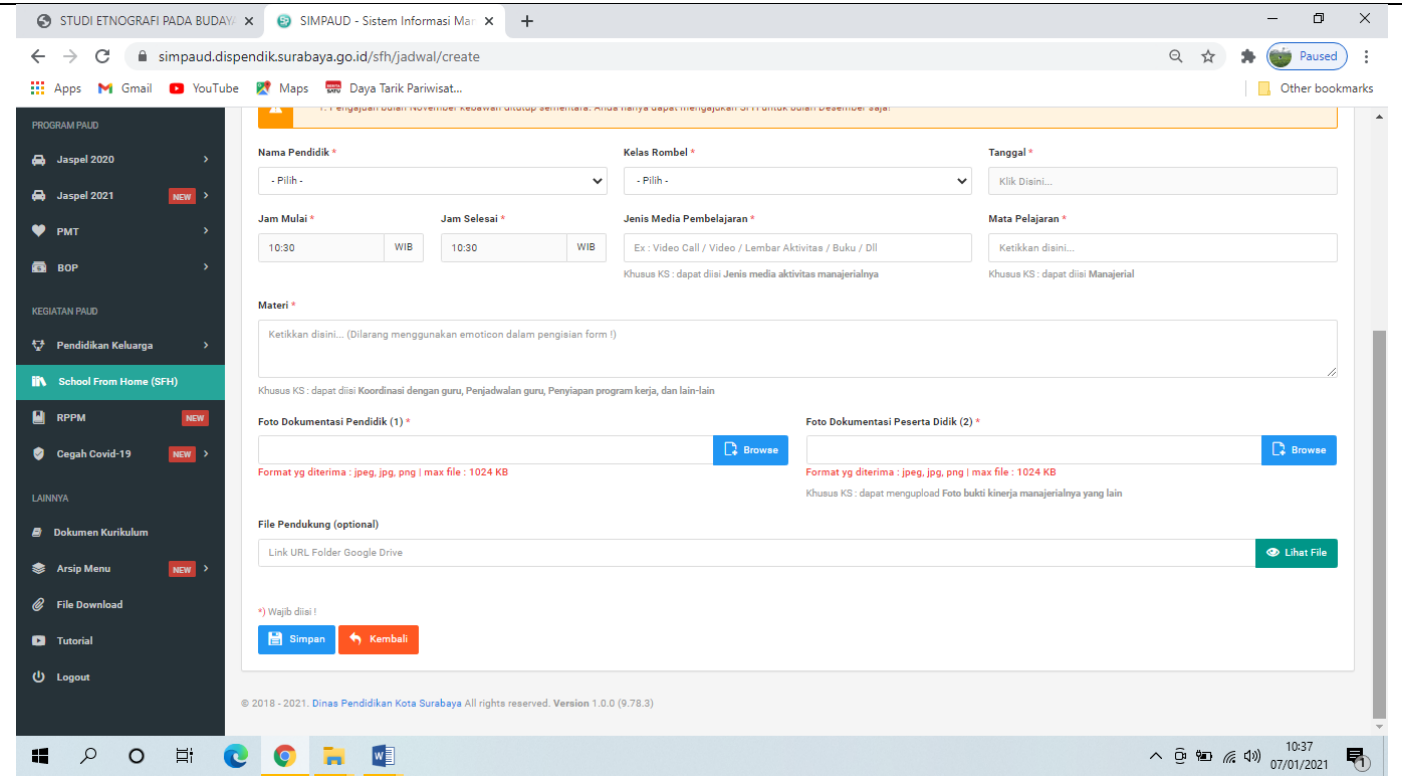

(11) File reports that must be attached to the results of the performance of teachers and school principals to the education office.

SIM PAUD applications can include teacher work activities by reporting learning outcomes carried out on students through various teaching methods. The teaching methods commonly used by Permata Hati PPT teachers are learning videos and student worksheets. All were reported with photo evidence of activities attached to the website of the education office of the city of Surabaya (Haris Budiman, 2017). This is directly proportional to the function of computer technology, namely technology related to computers, including equipment related to computers, where both parties are between teachers, principals, and supervisors to achieve the goal of good quality education (Bush, 2012).

\section{CONCLUSION}

The result of this research is the application of presentation model training and on-the-job training carried out by the principal to increase the knowledge and abilities of teachers in the field of technology. Where the principal provides examples and explanations at the beginning of the session, and then the teacher plays an active role in trying the skills that have been informed previously. This is useful to improve the ability of human resources owned. Before starting the training by the principal, she formed a lesson planning preparation team which was carried out online using the internet. This is done to prepare for the needs for training, both in the form of infrastructure and logistics needed. The existence of SIM PAUD as a means of exchanging information on the performance of educators, absenteeism, weekly Learning Program Plan documents between schools, teachers, and the Surabaya city education office.

\section{ACKNOWLEDGEMENT}

Thanks to various parties who have assisted in carrying out this research so that this paper can be completed. Thank you to the principal of PPT Permata Hati and all the teachers who have been the resource persons for this research.

\section{REFERENCES}

Bush, T. M. C. (2012). Manajemen MUtu. IRCiSoD.

Hakim, D. A., \& Si, M. (2007). Pengaruh kompetensi dan pengembangan karir terhadap kinerja sumber daya manusia melalui komitmen organisasi sebagai variabel intervening (studi pada kantor kecamatan mijen kabupaten demak).

Haris Budiman. (2017). Peran Teknologi Informasi Dan Komunikasi dalam Pendidikan. AlTadzkiyyah: Jurnal Pendidikan Islam, 8(1). 
Kamil, I. (2021). Setahun Covid-19 di Indonesia: Refleksi Pembelajaran Jarak Jauh dan Harapan Tatap Muka Lagi. Kompas.Com. https://nasional.kompas.com/read/2021/03/02/06583651/setahun-covid-19-diindonesia-refleksi-pembelajaran-jarak-jauh-dan-harapan?page=all

Kebudayaan, K. P. dan. (n.d.). Surat Edaran Nomor 15 Tahun 202020 Tentang Pedoman Penyelenggaraan Belajar Dari Rumah Dalam Masa Darurat Penyebaran Corona Virus Disease (COVID-19). Kebudayaan, Kementerian Pendidikan Dan.

Keselamatan, P., Kerja, K., Dan, K., \& Riyan, M. (2014). ( Studi Pada Pekerja bagian Produksi PT . SEKAWAN KARYATAMA MANDIRI Sidoarjo ). 9(1), 1-9.

M Husaini. (2014). Pemanfaatan Teknologi Informasi dalam Bidang Pendidikan (E-Education). JURNAL MIKROTIK, 2(1).

Mikrotik, J. (2014). PEMANFAATAN TEKNOLOGI INFORMASI DALAM BIDANG. 2(1).

Mulyasa. (2014). Pengembangan dan Implementasi Kurikulum. Remaja Rosdakarya.

Mustari, M. (2014). Manajemen Pendidikan (1st ed.). PT RajaGrafindo Persada.

Nugroho, Y. A. B. (2019). Pelatihan dan Pengembangan SDM. Universitas Katolik Indonesia Atma Jaya. Sallis, E. (2012). Total Quality Management In Education. IRCiSoD.

Sedarmayanti. (2009). Sumber Daya Manusia dan Produktivitas Kerja. CV Mandar Maju.

Sugiyono. (2018). Metode Penelitian Kualitatif (S. Y. Suryandari (ed.); 3rd ed.). CV Alfabeta.

Sukrispiyanto. (2019). Manajemen Sumber Daya Manusia. Indomedia Pustaka.

Suparto. (2016). MANAJEMEN SUMBER DAYA MANUSIA ( SDM ) GURU DALAM PENINGKATAN MUTU PENDIDIKAN DI MADRASAH IBTIDAIYAH AL-ISLAM KOTA BENGKULU. 275-285. 